\title{
KOHESI DAN KOHERENSI PARAGRAF DALAM KARANGAN NARASI MAHASISWA TEKNIK ANGKATAN 2017 UNIVERSITAS PGRI BANYUWANGI
}

\author{
Riska Fita Lestari \\ riskafl28@gmail.com
}

Universitas PGRI Banyuwangi

\begin{abstract}
Abstrak
Pentingnya melakukan penelitian analisis kohesi dan koherensi pada karangan narasi dari analisis bahasa lainya karena analisis ini cukup kompleks di perguruan tinggi. Kohesi diartikan sebagai kesatuan bentuk yang secara struktural membentuk ikatan sintaktik dalam wacana. Sedangkan koherensi adalah pertalian makna atau pertalian isi kalimat.pemahaman mahasiswa terhadap penyusunan karangan narasi berimplikasi pada karya tulis ilmiah. Permasalahan yang muncul adalah bagaimana kohesi dan koherensi paragraf dalam karangan narasi mahasiswa dan penanda kohesi dan koherensi apa saja yang sering digunakan dalam membuat karangan narasi mahasiswa teknik angkatan 2017 Universitas PGRI Banyuwangi. Tujuan penelitian ini untuk mengetahui kemampuan mahasiswa Jurusan teknik angkatan 2017. Penelitian ini dianalisis dengan metode analisis deskriptif kualitatif, yaitu data-data yang diperoleh diinterpretasikan dengan menelaah data, memeriksa keabsahan data, dan mendeskripsikan data Hasil ditemukannya dalam karangan narasi mahasiswa Teknik angkatan 2017 kohesi dan koherensi yang tidak merata. belum menunjukkan persyaratan kohesi dan koherensi yang baik, hal ini disebabkan kurangnya pemahaman mahasiswa dalam hal mamadukan kalimat satu dengan kalimat lainnya, belum adanya kelogisan dalam penyusunan paragraf.
\end{abstract}

Kata kunci: karangan narasi, koherensi, kohesi.

\section{Abstract}

The importance of conducting research analysis of cohesion and coherence in the narrative essay from other language analysis because this analysis is quite complex in college. Cohesion is defined as the unity of the form that structurally establishes the synthetic bonds in discourse. While the coherence is a connection to the meaning or relevance of the sentence. Students ' understanding of the narrative drafting is implicit implications on scientific writings. The problem that arises is how the cohesion and coherence of paragraphs in the student narrative essays and markers of cohesion and coherency of just about anything that is often used in making a narrative essay student engineering Force 2017 PGRI University Banyuwangi. The purpose of this research is to know the skills of students in engineering department 2017. The research was analyzed by qualitative descriptive analysis methods, i.e. the data obtained interpreted by studying the data, examining the validity of the data, and describing the data the results found in the narrative essay of engineering students Force 2017 cohesion and uneven coherence. has not demonstrated the requirement of good cohesion and coherence, this is due to the lack of understanding of students in terms of the sentence one with other sentences, there is no straightness in the drafting of paragraphs.

Key words: coherence, cohesion, narrative essay.

\section{PENDAHULUAN}

Manusia mempunyai berbagai kultur budaya dan ragam bahasa yang berbeda, hal ini dikarenakan manusia sebagai makhluk sosial tinggal di berbagai wilayah yang berbeda-beda pula. Bahasa merupakan salah satu faktor penting dalam kehidupan manusia, bahasa adalah sarana berkomunikasi antar manusia untuk saling berhubungan satu sama lain untuk meningkatkan kemampuan intelektual, bertukar informasi dan pengalaman agar dapat saling memahami satu sama lain.

Andayani (2015:191) Analisis wacana memiliki peranan yang sangat penting dalam pembelajaran bahasa, terutama dalam keterampilan berbahasa yang bersifat produktif yaitu berbicara dan menulis.

Wacana adalah suatu upaya pengungkapan maksud tersembunyi dari sang subjek yang mengemukakan suatu pernyataan. Pemahaman tentang wacana merupakan upaya memahami unsur kebahasaan yang relatif lebih kompleks dan lebih lengkap. Sedangkan menurut Sumarlam 2003: 23). Dapat dikatakan wacana yang baik adalah wacana yang harus memperhatikan hubungan antarkalimat, sehingga dapat memelihara keterkaitan dan keruntutan antarkalimat. 
Sejalan dengan pandangan bahwa bahasa itu terdiri atas bentuk dan makna, hubungan dalam wacana dapat dibedakan menjadi dua jenis yaitu hubungan bentuk yang disebut kohesi dan hubungan makna atau hubungan semantis yang disebut Kedua jenis hubungan bentuk dan makna tersebut menjadi salah satu syarat terbentuknya sebuah wacana.

Susanto (2013: 241), ada empat aspek keterampilan berbahasa Indonesia yaitu mendengar (menyimak), berbicara, membaca, dan menulis. Keempat aspek ini saling terkait antara satu dengan yang lainnya. Sehingga dapat diartikan bahwa keempat aspek keterampilan sangat terkait, tetapi keterampilan Menulis merupakan keterampilan yang sangat rumit dari keterampilan lainnya.

Suparno (2009: 1.26). Menulis memiliki tingkat kesukaran lebih tinggi dibandingan dengan tiga keterampilan berbahasa yang lain. Karena menulis merupakan kegiatan yang kompleks. Disebut kegiatan kompleks karena penulis dituntut untuk dapat menyusun dan mengorganisasikan isi tulisannya serta menuangkannya dalam formulasi ragam bahasa tulis dan konvensi penulisan lainnya.

Pada karangan narasi pada mahasiswa banyak sekali hambatan dalam memahami ada tidaknya unsur kohesi dan koherensi dalam setiap paragraf yang dibuatnya. Hal tersebut disebabkan oleh banyaknya kesalahan dalam penulisan.

Selain aspek kohesi, sebuah wacana atau karangan yang baik juga harus mempunyai aspek koherensi. Koherensi adalah pertalian atau jalinan antar kata atau kalimat dalam teks (Eriyanto, 2001: 242). Berbeda dengan kohesi, aspek koherensi secara struktural membentuk ikatan sematik.

Aspek kohesi dan koherensi sangat berkaitan dengan keterampilan menulis karangan. Dalam penelitian ini lebih difokuskan pada karangan narasi. Karangan narasi merupakan karangan yang menuntut penulis mampu menerangkan, menguraikan, atau menjelaskan suatu kejadian atau peristiwa berdasarkan urutan waktu untuk dapat menambah pengetahuan pembacanya. Menulis karangan narasi bukan merupakan kegiatan mengarang yang mudah tetapi penulis harus memahami konsep penulisan dan tujuan karangan narasi yaitu menguraikan suatu peristiwa dengan tujuan memberikan informasi mengenai suatu peristiwa. Agar corak karangan yang dihasilkan nanti sesuai dengan kaidah yang benar (Djuharie dan Suherli, 2001: 49). Pemilihan karangan narasi sebagai fokus penelitian adalah pembaca dapat memperoleh pengetahuan baru dari data penelitian yang ditulis oleh mahasiswa.

Selain itu dalam menulis sebuah paragraf mahasiswa banyak terdapat kekeliruan karena memiliki pemahaman yang salah. mahasiswa beranggapan kalau paragraf penulisannya berbentuk alinea baru yang secara teknik penulisannya agak menjorok ke dalam dari bagian lain. Banyak ditemui paragraf pada karangan mahasiswa itu tidak mempunyai ide pokok atau merupakan bagian dari paragraf sebelumnya. Padahal selain harus mengandung kohesi dan koherensi, paragraf yang baik juga harus mempunyai satu ide pokok dan satu atau beberapa ide pengembang .

Hasil penelitian ini dapat memberikan gambaran kemampuan mahasiswa dalam menulis karangan narasi dengan syarat paragraf yang kohesi dan koherensi. Selain itu, hasil penelitian ini juga dapat menjadi barometer tingkat keberhasilan pembelajaran bidang studi matakuliah bahasa Indonesia khususnya di tingkat perguruan tinggi tersebut dalam mengajarkan membuat karangan dengan paragraf yang kohesi dan koherensi.

Berdasarkan uraian tersebut bahwa keterampilan menulis merupakan sebuah proses tidak didapat secara serta merta. Selain pemahaman konsep atau teori menulis, mahasiswa juga harus melakukan latihan. Latihan dilakukan untuk 
menerapkan pemahaman mahasiswa tentang menulis karangan terhadap keterampilan menulis. Oleh sebab itu peneliti mengambil judul penelitian yaitu "Kohesi dan Koherensi Paragraf dalam Karangan Narasi Mahasiswa Teknik angkatan 2017 Universitas PGRI Banyuwangi ". Dengan rumusan masalah yang peneliti ambil dari penelitian ini adalah; bagaimanakah kohesi dan koherensi paragraf dalam karangan narasi mahasiswa, apa sajakah penanda kohesi dan koherensi yang sering digunakan dalam karangan narasi mahasiswa.

\section{KAJIAN TEORI}

\section{Pengertian Wacana}

Dari asal usul katanya, kata "wacana" berasal dari bahasa Sansekerta, yaitu dari kata vacana yang berarti "bacaan". Kata wacana itu, masuk ke dalam bahasa Jawa Kuno menjadi wacana [wacana] dan selanjutnya masuk ke dalam bahasa Jawa Baru menjadi wacana [wacana] yang berarti bicara, kata, ucapan. Kata wacana di dalam bahasa Jawa Baru itu diserap ke dalam bahasa Indonesia menjadi "wacana"e yang berarti "komunikasi verbal, percakapan". Penjelasan di atas disampaikan oleh Wedhawati, (2006: 595).

Wacana adalah satuan bahasa terlengkap dalam hierarki gramatikal, merupakan satuan gramatikal tertinggi atau terbesar. Menurut Kridalaksana (2008: 259) wacana dalam bahasa inggris disebut discourse adalah satuan bahasa terlengkap, dalam hierarki gramatikal merupakan satuan gramatikal tertinggi atau terbesar. Hampir sama pendapatnya, menurut Chaer (2012: 267) wacana adalah satuan bahasa yang terlengkap, sehingga dalam herarki gramatikal merupakan satuan gramatikal tertinggi atau terbesar wacana dikatakan lengkap karena di dalamnya terdapat konsep, gagasan, pikiran atau ide yang utuh, yang bisa dipahami oleh pembaca (dalam wacana tulis) atau oleh pendengar (dalam wacana lisan) tanpa keraguan apapun.

Berdasarkan pendapat yang telah dikemukakan di atas, dapat disimpulkan bahwa wacana adalah satuan bahasa terlengkap dan tertinggi yang direalisasikan dalam bentuk karangan utuh seperti buku, novel, seri ensiklopedia, dsb.

Wacana dikatakan tertinggi atau terbesar karena wacana dibentuk dari kalimat atau kalimat-kalimat yang memenuhi persyaratan gramatikal dan persyaratan kewacanaan lainnya. Persyaratan gramatikal dalam wacana dapat dipenuhi jika dalam wacana itu sudah terbina yang disebut kekohesian, yaitu adanya keserasian hubungan antara unsur-unsur yang ada dalam wacana tersebut. Bila wacana itu kohesif, akan terciptalah kekoheresian, yaitu isi wacana yang apik dan benar. Makna dan kerapian bentuk merupakan faktor penting untuk menentukan tingkat keterbacaan dan keterpahaman wacana. Sebuah wacana dapat dikatakan baik apabila hubungan antarkalimat-kalimatnya kohesif dan koheren. Maka dari itu, dibutuhkan penanda koherensi untuk mencapai kekohesifan yang mantap sehingga wacana tersebut dapat dikatakan wacana yang utuh karena terdapat kohesi dan koherensi yang lengkap.

Menurut realitasnya wacana merupakan verbal dan nonverbal, wujud wacana berdasarkan media komunikasi berupa rangkaian ujaran (tuturan) lisan dan tulis, sedangkan berdasarkan pemaparan wacana, dapat memperoleh jenis wacana yang disebut naratif, deskriptif, prosedural, ekspositori, dan hortatori, dari jenis pemakaian wacana wujud monolog (satu orang penutur), dialog (dua orang penutur), dan prolog (lebih dari dua orang penutur).

Berdasarkan media penyampaiannya, wacana dapat dipilih menjadi dua, yaitu wacana tulis dan wacana lisan. 


\section{Wacana Tulis}

Wacana tulis (written discourse) adalah jenis wacana yang disampaikan melalui tulisan. Berbagai bentuk wacana sebenarnya dapat dipresentasikan atau direalisasikan melalui tulisan. Hingga saat ini, tulisan masih merupakan media yang sangat efektif dan efisien untuk menyampaikan berbagai gagasan, wawasan, ilmu pengetahuan, atau apapun yang dapat mewakili kreativitas manusia.

\section{Wacana Lisan}

Wacana lisan (spoken discourse) adalah jenis wacana yang disampaikan secara lisan atau langsung dengan bahasa verbal. Jenis wacana ini sering disebut sebagai tuturan (speech) atau ujaran (utterance). Adanya kenyataan bahwa pada dasarnya bahasa kali pertama lahir melalui mulut/lisan. Oleh karena itu, wacana yang utama, primer, dan sebenarbenarnya adalah wacana lisan.

\section{Pengertian Paragraf}

Dalman (2015: 77) pengertian paragraf terdapat dalam pemakaian bahasa secara tertulis. Sebuah paragraf terdiri atas beberapa kalimat atau lebih dari satu kalimat. Sedangkan Tarigan (2008: 5) paragraf adalah seperangkat kalimat tersusun logis sistematis yang merupakan satu kesatuan ekspresi pikiran yang relevan dan mengandung pikiran pokok yang tersirat dalam keseluruhan.

Fungsi Paragraf Menurut Tarigan (2008: 5) fungsi paragraf dapat disimpulkan sebagai berikut: 1. sebagai penampung dari sebagian kecil jalan pikiran atau ide pokok keseluruhan karangan; 2. memudahkan pemahaman jalan pikiran atau ide pokok pengarang; 3 . alat bagi pengarang untuk mengembangkan jalan pikiran secara sistematis; 4. pedoman bagi pembaca untuk mengikuti dan memahami alur pikiran pengarang; 5 . sebagai penyampai pikiran atau ide pokok pengarang kepada pembaca; 6. sebagai penanda bahwa pikiran baru dimulai; 7. dalam rangka keseluruhan karangan, paragraf dapat berfungsi sebagai pengantar, transisi, dan penutup (konklusi)

Dalman (2015: 88) Syarat-syarat paragraf yang baik paragraf yang baik adalah paragraf yang memiliki kepaduan antara unsur-unsurnya baik itu antara gagasan utama dengan gagasan penjelasnya ataupun antara kalimatkalimatnya. Sedangkan menurut Mustakim, (1994: 115-116) sebagai suatu bentuk pengungkapan gagasan, sebuah paragraf yang baik hendaknya dapat memenuhi dua kriteria atau persyaratan, yaitu sebagai berikut. Kesatuan (Kohesi). Kepaduan (Koherensi) Kriteria kesatuan atau kohesi menyangkut keeratan hubungan makna antargagasan dalam sebuah paragraf, sedangkan kriteria kepaduan menyangkut keeratan hubungan antar kalimat dalam paragraf dari segi bentuk atau strukturnya. Menurut Dalman (2015: 48) menjelaskan bahwa persyaratan paragraf mencakup:

1. Persyaratan kesatuan keutuhan

2. Persyaratan pengembangan

3. Persyaratan kepaduan atau koherensi 4. Persyaratan kekompakan atau kohesi

Dari beberapa pendapat tokoh diatas dapat disimpulkan bahwa syarat paragraf yang baik adalah dalam sebuah paragraf hendaknya memenuhi syarat kesatuan (kohesi) dan kepaduan (koheren). Maksud dari kesatuan yaitu dalam sebuah paragraf hanya memiliki satu gagasan utama atau kalimat utama, sedangkan maksud dari kepaduan adalah dalam sebuah paragraf hendaknya memperlihatkan hubungan antarkalimat yang mendukung kalimat utama atau gagasan pokok.

\section{Pengertian Kohesi}

Kohesi adalah keserasian hubungan antara unsur-unsur yang satu dengan unsur yang lain dalam wacana sehingga tercipta pengertian yang baik (koheren). Kalimat atau kata yang dipakai bertautan dan saling mendukung makna. Pengertian yang satu menyambung pengertian yang lainnya sehingga berturut-turut. Dengan demikan ada wacana yang kohesif, koheren dan ada wacana yang tidak kohesif 
dan koheren. Pendapat tersebut dikemukakan oleh Djajasudarma (2006: 44). Pendapat lain yang berkaitan dengan kohesi dikemukakan oleh Mulyana (2005: 26) bahwa kohesi dalam wacana diartikan sebagai kepaduan bentuk secara struktural membentuk ikatan sintaktikal.

Konsep kohesi pada dasarnya mengacu kepada hubungan bentuk artinya, unsur-unsur wacana (kata atau kalimat) yang digunakan untuk menyusun suatu wacana memiliki keterkaitan secara padu dan utuh. Dengan kata lain, kohesi termasuk dalam aspek internal struktur wacana. Sehubungan dengan hal tersebut, Mulyana (2005: 26) mengemukakan bahwa penelitian terhadap unsur kohesi menjadi bagian dari kajian aspek formal bahasa. Oleh karenanya, organisasi dan struktural kewacanaannya juga berkonsentrasi dan bersifat sintaktik-gramatikal.

Dalam karangan atau wacana, kohesi diartikan sebagai kesatuan bentuk yang secara struktural membentuk ikatan sintaktik. Menurut Keraf (2001: 87) paragraf kohesi merupakan paragraf yang memiliki kesatuan semua kalimat yang membangunnya secara bersamasama menyatakan suatu hal atau tema tertentu. Oleh karena itu sering kehadiran kohesi ditandai dengan pemarkah atau penanda. Untuk selanjutnya akan digunakan kata penanda.

Kohesi dibedakan menjadi dua yaitu kohesi gramatikal dan kohesi leksikal. Kohesi gramatikal terdiri dari referensi, subtitusi, elipsis dan konjungsi. Sedangkan kohesi leksikal berupa sinonim, hiponim, repetisi, kolokasi, dan ekuivalensi. Berikut akan dijelaskan lebih lanjut tentang istilah-istilah tersebut.

\section{Kohesi Gramatikal}

Kohesi gramatikal adalah kohesi yang membangun gramatik wacana. Kohesi gramatikal terdiri dari referensi, subtitusi, elipsis dan konjungsi. Berikut ini penjelasan dari unsur-unsur tersebut.

Referensi merupakan bagian kohesi yang berkaitan dengan penggunaan kata atau kelompok kata untuk menunjuk kata atau kelompok kata lainnya (Ramlan, 1933:12). Referensi endoforik masih dibedakan menjadi dua yaitu referensi endoforik anafora dan referensi endoforik katafora. Referensi endoforik anafora merujuk pada kata sebelumnya.

Tarigan (2008: 101) Subtitusi adalah proses dan hasil penggantian bahasa oleh unsur lain dalam satuan yang lebih besar. Penggantian dilakukan untuk memperoleh unsur pembeda atau menjelaskan unsur tertentu yang telah disebutkan sebelumnya.

$$
\text { Elipsis (pelesapan) adalah }
$$

peniadaan atau penghilangan kata atau satuan lain, yang wujud asalnya dapat diramalkan dari konteks bahasa atau konteks luar bahasa (Kridalaksana, 2008: 50). Elipsis merupakan penggantian unsur kosong, yaitu unsur yang sebenarnya ada tetapi sengaja dihilangkan atau disembunyikan. Tujuannya adalah untuk efisiensi yaitu mendapatkan kepraktisan bahasa, singkat dan padat, serta mudah dimengerti.

Konjungsi adalah kategori yang menghubungkan kata dengan kata, klausa dengan klausa, atau kalimat dengan kalimat, dapat juga paragraf dengan paragraf (Chaer, 2009: 81). Konjungsi dibagi menjadi dua yaitu konjungsi koordinatif dan konjungsi subordinatif. Konjungsi koordinatif adalah konjungsi yang menghubungkan dua buah konstituen yang kedudukannya sama atau sederajat. Konjungsi subordinatif adalah konjungsi yang menghubungkan dua buah konstituen yang kedudukannya tidak sederajat atau bertingkat.

\section{Kohesi Leksikal}

Kohesi leksikal adalah hubungan leksikal antara bagian-bagian wacana untuk mendapatkan keserasian struktur secara kohesif. Penanda yang termasuk kohesi leksikal antara lain sinonim, hiponim, repetisi, kolokasi, dan ekuivalensi. Perhatikan contoh berikut ini:

1. sinonim : mahir, ahli

2. hiponim : angkutan darat (kereta api, 
bus, taksi)

3. repetisi : pengulangan kata yang sama

4. kolokasi : buku, koran, majalah

5. antonim : tua-muda

6. ekuivalensi : belajar, mengajar, pelajar, pengajar, pelajaran.

Tujuan digunakan kohesi leksikal untuk mendapatkan efek intensitas makna bahasa, kejelasan informasi, dan keindahan bahasa.

\section{Koherensi}

Koherensi adalah pertalian makna atau pertalian isi kalimat (Tarigan, 2008: 32). Koherensi sangat diperlukan keberadaannya untuk menata pertalian batin antara bagian yang satu dengan yang lain dalam paragraf. Keberadaan unsur koherensi sebenarnya tidak pada satuan teks semata, melainkan juga pada kemampuan pembaca atau pendengar dalam menghubungkan makna dan menginterpretasikan suatu bentuk wacana yang diterimanya. Tarigan (2008: 104) membagi unsur penanda koherensi diantaranya adalah penambahan, komparasi, penekanan, kontras, simpulan, contoh, pararelisme, tempat dan waktu. Berbeda dengan Kridalaksana (Tarigan, 2008: 38) yang mengungkapkan penanda hubungan koherensi dalam wacana antara lain hubungan sebab-akibat, hubungan sarana-hasil, hubungan alasan-sebab, hubungan sarana-tujuan, hubungan latarkesimpulan, hubungan kelonggaran-hasil, hubungan syarat-hasil, hubungan perbandingan, hubungan parafrasis, hubungan amplikatif, hubungan adiftif waktu, hubungan adiftif nonwaktu, hubungan identifikasi, hubungan generikspesifik, dan hubungan ibarat.

\section{Perbedaan Kohesi dan Koherensi}

Kohesi dan koherensi sebenarnya hampir sama karena penanda aspek kohesi juga merupakan penanda aspek koherensi. Demikian pula sebaliknya. Namun, keduanya memiliki perbedaan. Perbedaan keduanya terletak pada titik dukung terhadap struktur wacana. Aspek yang mendukung keutuhan wacana dari dalam (internal) disebut aspek kohesi. Sedangkan Aspek yang mendukung keutuhan wacana dari luar (eksternal) disebut aspek koherensi (Parera, 2009: 218). Tabel berikut menggambarkan perbedaan keduanya.

Tabel 1. Perbedaan kohesi dan koherensi

\begin{tabular}{|l|l|}
\hline \multicolumn{1}{|c|}{ Kohesi } & \multicolumn{1}{c|}{ Koherensi } \\
\hline Kepaduan & Kerapian \\
Keutuhan & Kesinambungan \\
Aspek bentuk & Aspek makna \\
Aspek lahiriah & Aspek batiniah \\
Aspek formal & Aspek ujaran \\
Organisasi & Organisasi sematik \\
sintaktik & Unsur eksternal \\
Unsur internal & \\
\hline
\end{tabular}

Sumber : Dardiri (2008: 35-36) Analisis Wacana bahasa Indonesia

\section{Karangan Narasi}

Semi (2003:29) Narasi merupakan bentuk percakapan atau tulisan yang bertujuan menyampaikan atau menceritakan rangkaian peristiwa atau pengalaman nmanusia berdasarkan perkembangan dari waktu ke waktu Ragam atau jenis karangan pada umumnya dikelompokkan ke dalam empat jenis yaitu narasi, deskripsi, narasi, dan argumentasi. Narasi sebagai bentuk wacana, dapat menjadi suatu bentuk tulisan yang berdiri sendiri dan mempunyai struktur. Itu dapat dilihat dari bermacam-macam segi penglihatan. Sesuatu dapat dikatakan mempunyai struktur, bila ia terdiri dari bagian-bagian yang secara fungsional berhubungan satu ama lain. Bagian-bagian itu tergantung dari cara melihat barang itu.

\section{METODE PENELITIAN}

Penelitian ini termasuk penelitian deskriptif. Dimana dilakukan analisis hubungan kohesi dan koherensi paragraf dalam karangan narasi. Subjek dalam penelitian ini adalah mahasiswa teknik mesin angkatan 2017 Universitas PGRI Banyuwangi Jember yang berjumlah 24 mahasiswa terdiri dari 9 teknik elektro dan 15 teknik mesin. 
Penelitian ini mengambil jenis dokumen sebagai objek penelitian, sehingga metode yang digunakan dalam penelitian ini merupakan metode deskriptif kualitatif. Metode kualitatif, yaitu pengamatan, wawancara, atau penelaah dokumen (Moleong, 2016: 9). Metode kualitatif ini digunakan karena beberapa pertimbangan. Pertama, menyesuaikan metode kualitatif lebih mudah apabila berhadapan dengan kenyataan jamak. Kedua, metode ini menyajikan secara langsung hakikat hubungan antara peneliti dan responden. Ketiga, metode ini lebih peka dan lebih dapat menyesuaikan diri dengan banyak penajaman pengaruh bersama terhadap pola-pola nilai yang dihadapi. Pendekatan dalam penelitian ini menggunakan pendekatan deskriptif dengan metode analisis dokumen (content analysis)

Metode pengumpulan data yang digunakan dalam penelitian ini adalah studi dokumenter dan non tes. Teknik uji validitas atau keabsahan data menurut Moleong (2016:330) menjelaskan triangulasi adalah teknik pemeriksaan keabsahan data yang memanfaatkan sesuatu yang lain. Sebagai teknik pemeriksaan, terdapat empat macam triangulasi, yakni: (1) pemanfaatan menggunakan sumber data, (2) metode, (3) penyidikan, dan (4) teori.

Teknik analisis data yang digunakan dalam penelitian kualitatif deskriptif ini adalah teknik analisis data interaktif. Hal tersebut dikarenakan data yang diperoleh adalah data tetap atau tidak berubah berupa kumpulan karangan paragraf narasi mahasiswa teknik.

Untuk mendapatkan data diperlukan adanya alat pengambil data yang biasa disebut instrumen penelitian (Chaer, 2009: 37). Dalam setiap penelitian, instrumen penelitian menentukan kualitas data yang dapat dikumpulkan, sedangkan kualitas data akan dapat menentukan hasil penelitian yang dihasilkan. Penelitian ini bersifat pengamatan pada objek, oleh karena itu instrumen penelitian disesuaikan dengan tujuan penelitian.

Instrumen yang digunakan dalam penelitian ini adalah instrumen non tes yaitu berupa penugasan kepada responden untuk dihimpun hasilnya. Hasil dari instrumen ini adalah data deskriptif kualitatif. Dalam studi dokumenter dimungkinkan diperoleh data berupa angka yang dapat diolah menjadi data nominal (Sukmadinata, 2007: 233). Akan tetapi dalam penelitian ini tidak akan dijumpai angka karena fokus penelitian ini berupa karangan. Karangan siswa dianalisis kemudian dideskripsikan bukan diberikan penilaian berupa angka.

\section{HASIL DAN PEMBAHASAN}

\section{Karangan siswa}

Karangan 24 dengan tema "Geliat Kampusku". Karangan ini terdiri dari lima paragraf satu paragraf dengan empat kalimat. Paragraf tersebut sudah memenuhi syarat kohesi dan koherensi.

Karangan 1, 2. 3, 5, 6, 7, 8, 11, 12, $14,15,16,18,19,20,22,23,24$ pada karangan mahasiswa tersebut terdiri dari maksimal tujuh paragraf. Paragraf pertama terdiri dari lima sampai enam kalimat dan paragraf kedua terdiri dari tiga kalimat.

Kedua paragraf dalam karangan 1 ini sudah memiliki unsur kohesi dan koherensi paragraf. Hal tersebut dapat dibuktikan dengan adanya unsur penanda kohesi dan koherensi. Penanda kohesi dalam paragraf pertama adalah referensi endoforik katafora, substitusi, repetisi dan konjungsi.

Karangan 4, 9, 10, 13, 17, 21 pada karangan mahasiswa teknik ini punya kesamaan kriteria yaitu terdiri dari maksimal dua paragraf. Masing-masing paragraf hanya terdiri dari satu kalimat. Oleh sebab itu, karangan tersebut tidak memiliki syarat kohesi dan koherensi paragraf. Karena tidak terdapat kalimat pengembang yang menyatakan kohesi dan koherensi paragraf. Selain itu, pada 
dasarnya paragraf kedua dalam karangan tersebut merupakan bagian dari paragraf pertama. Kesalahan terjadi pada teknik penulisan.

\section{Penanda Kohesi}

Konsep kohesi pada dasarnya mengacu kepada hubungan bentuk artinya, unsur-unsur wacana (kata atau kalimat) yang digunakan untuk menyusun suatu wacana memiliki keterkaitan secara padu dan utuh. Dengan kata lain, kohesi termasuk dalam aspek internal struktur wacana. Sehubungan dengan hal tersebut, Mulyana (2005: 26) mengemukakan bahwa penelitian terhadap unsur kohesi menjadi bagian dari kajian aspek formal bahasa. Oleh karenanya, organisasi dan struktural kewacanaannya juga berkonsentrasi dan bersifat sintaktikgramatikal.

Wacana sebagai satu pesan yang lengkap berhubungan dengan banyak fenomena kebahasaan. Salah satu fenomena wacana yang menjadi perhatian adalah kekohesifan dan kekoherensian sebuah wacana. Menurut Wedhawati, dkk (2006: 604) kohesi adalah hubungan bahasa di dalam wacana atau teks. Sebuah teks terbentuk jika satuan-satuan bahasa pembentuknya berhubungan secara gramatikal dan sistematis. Berdasarkan penandanya, kohesi dibedakan menjadi dua, yaitu kohesi gramatikal dan kohesi leksikal. Kohesi gramatikal adalah hubungan antarsatuan bahasa pembentuk teks dengan penanda satuan gramatikal tertentu. Kohesi leksikal adalah hubungan antarsatuan bahasa secara semantik leksikal di dalam teks yang sama.

Penanda kohesi yang sering digunakan dalam karangan narasi mahasiswa adalah referensi endoforik anafora, referensi endoforik katafora, sinonim, konjungsi, repetisi, subtitusi, dan elipsis. Masing-masing penanda kohesi tersebut akan dijabarkan berikut ini.

\section{Referensi endoforis anafora}

Referensi endoforis anafora merupakan penanda kohesi yang merujuk pada pernyataan sebelumnya. Referensi endoforis anafora ini antara lain terdapat pada karangan 1, karangan 10, karangan 17, karangan 18 dan karangan 24. Dalam karangan 3 terdapat pada kalimat ketiga paragraf pertama yaitu kelompok kata hal ini yang merujuk pada pernyataan dalam kalimat sebelumnya yaitu kalimat pertama. Karangan 8, penanda ini terdapat pada kelompok kata sekolah ini dalam kalimat kedua paragraf pertama yang merujuk pada kelompok kata Universitas PGRI Banyuwangi dalam kalimat pertama. Kemudian dalam karangan 17, penanda referensi endoforik anafora yaitu kata ini dalam kalimat kedua paragraf kedua yang merujuk pada kelompok kata batrei pada kalimat sebelumnya yaitu kalimat pertama.

\section{Referensi Endoforis Katafora}

Referensi endoforis katafora merupakan penanda kohesi yang merujuk pada pernyataan sesudahnya. Referensi endoforis katafora ini antara lain terdapat pada karangan 1, karangan 2, karangan 3, karangan 12, karangan 15, karangan 18. Karangan 1, penanda ini terdapat pada kelompok kata berikut ini dalam kalimat pertama paragraf pertama yang merujuk pada pernyataan sesudahnya. Penanda ini terdapat kelompok kata berikut ini dalam kalimat pertama paragraf pertama yang merujuk pada pernyataan sesudahnya. Dalam karangan 15, referensi endoforik katafora terdapat pada kelompok kata berikut ini dalam kalimat pertama yang merujuk pada pernyataan sesudahnya. Sedangkan dalam karangan 18, penanda referensi endoforik katafora dapat dilihat dari kelompok kata berikut ini dalam kalimat pertama yang merujuk pada pernyataan sesudahnya. Kelompok kata berikut ini sama-sama menandai adanya penanda referensi endoforik katafora.

\section{Sinonim}

Sinonim merupakan bagian dari penanda kohesi leksikal yang menyatakan persamaan makna kata atau kelompok kata. Dalam karangan ini penanda sinonim digunakan sebanyak dua kali yaitu pada

80| Jurnal Kredo Vol. 3 No. 1 Oktober 2019 
karangan 6, karangan 14, karangan 18 dan karangan 23. dalam karangan 6, 14, 18 Sinonim terdapat pada kata munculnya pada kalimat ketiga paragraf kedua yang merupakan padanan dari kata keluarnya pada kalimat pertama. Sedangkan dalam karangan 23, Sinonim terdapat pada kata jam yang merupakan padanan dari kata jadwal.

\section{Konjungsi}

Konjungsi merupakan salah satu penanda kohesi gramatikal yang berupa kata penghubung antar dua buah konstituen. Dalam hal ini konstituen yang sering digunakan adalah kalimat. Konjungsi dalam karangan narasi mahasiswa ini terdapat pada karangan 1, karangan 2, karangan 6, karangan 9, karangan 12, dan karangan 15. Karangan 1, Konjungsi dapat dilihat dari kata kemudian dalam kalimat keenam paragraf kedua yang menyatakan pengurutan. Karangan 2, dapat dilihat dengan adanya penanda konjungsi sedangkan dalam kalimat kedua paragraf kedua yang menyatakan pertentangan dari kalimat pertama. Karagan 9, penanda ini terdapat pada kata lalu dalam kalimat ketiga paragraf kedua yang menyatakan pengurutan. Dalam karangan 12, penanda konjungsi terdapat pada kata yaitu pada kalimat kedua paragraf kedua. Begitu juga dalam karangan 15, penanda ini dapat dilihat pada kata apabila dalam kalimat keenam dan kata setelah dalam kalimat ketujuh yang menyatakan hubungan syarat.

\section{Repetisi}

kohesi leksikal yang merupakan pengulangan kata atau kelompok kata. Repetisi ini terdapat dalam karangan 1, karangan 2, karangan 6, karangan 7, karangan 14, karangan 15, karangan 18, karangan 18 dan karangan 24. Karangan 1, repetisi terdapat pada kelompok kata remot kontrol dalam paragraf pertama kalimat kedua yang diulang dalam kalimat ketiga, kemudian kelompok kata memilih tempat dalam kalimat keempat yang diulang dalam kalimat kelima.

\section{Subtitusi}

Subtitusi merupakan unsur penanda kohesi gramatikal yaitu penggantian kata atau kelompok kata dengan kata atau kelompok kata yang berbeda dengan tujuan memperjelas maksud. Subtitusi dalam karangan narasi mahasiswa ini terdapat pada karangan 1, karangan 3, karangan 9, karangan 12, karangan 14, dan karangan 15. Karangan 1, penanda subtitusi terdapat pada penggantian kelompok kata langkah-langkah dalam kalimat pertama paragraf pertama menjadi kelompok kata langkah awal dalam kalimat kedua dan kelompok kata langkah kedua dalam kalimat keempat.

\section{Elipsis}

Elipsis merupakan penanda kohesi gramatikal yaitu penghilangan kata atau kelompok kata dengan tujuan efisiensi bahasa dan kemudahan memahami bahasa. Penanda elipsis ini terdapat pada karangan 9 dan karangan 15. Dalam karangan 9 dapat dilihat pada kalimat keempat paragraf pertama yaitu kelompok kata panci yang sudah terisi air yang sengaja dihilangkan karena sudah disebutkan dalam kalimat ketiga dengan tujuan efisiensi bahasa. Kemudian dalam karangan 15 penanda elipsis terdapat pada kalimat kelima yaitu penggunaan penghilangan kelompok kata panci diatas kompor karena sudah disebutkan dalam kalimat sebelumnya.

\section{Penanda Koherensi}

Penanda koherensi yang terdapat dalam karangan ini antara lain adalah penanda hubungan cara, hubungan penjelasan, hubungan rentetan, hubungan identifikasi, latar-kesimpulan, dan hubungan alasan-sebab. Penanda hubungan cara terdapat pada karangan 1, karangan 2 paragraf pertama, karangan 6 , karangan 14 paragraf ketiga, karangan 15, dan karangan 20. penanda hubungan penjelasan terdapat pada karangan 7, karangan 12, karangan 14 paragraf dua dan lima, karangan 17 paragraf kedua. Penanda 
hubungan rentetan terdapat pada karangan 3 paragraf pertama dan karangan 18 . Penanda hubungan identifikasi terdapat pada karangan 17 paragraf pertama. Penanda hubungan latar-kesimpulan terdapat pada karangan 2 paragraf pertama. Kemudian penanda hubungan alasan-sebab terdapat pada karangan 18 paragraf pertama.

\section{SIMPULAN}

Berdasarkan data yang diperoleh
dari hasil penelitian dapat ditarik
kesimpulan yaitu sebagai berikut.
1. Data penelitian berjumlah 24
karangan dari 24 responden. Setelah
dilakukan pengecekan keabsahan data
sesuai fokus penelitian yaitu karangan
narasi, data yang memenuhi kriteria
karangan narasi berjumlah 18

karangan dilihat dari ciri-ciri dan pola pengembangan paragraf.

2. Karangan mahasiswa yang dibahas dalam penelitian ini berjumlah 18 karangan narasi. Penanda kohesi dan yang sering digunakan mahasiswa teknik angkatan 2017 Universitas PGRI Banyuwangi dalam membuat karangan narasi adalah referensi endofora anafora, referensi endofora katafora, sinonim, konjungsi, repetisi, subtitusi, dan elipsis. Sementara itu penanda hubungan koherensi yang sering digunakan mahasiswa adalah penanda hubungan cara, hubungan penjelasan, hubungan rentetan, hubungan identifikasi, latarkesimpulan, dan hubungan alasansebab.

\section{DAFTAR PUSTAKA}

Andayani. 2015. Problema dan Aksioma dalam Metodologi Pembelajaran Bahasa Indonesia. Yogyakarta: Deepublish.

Chaer. Abdul.2012. Linguistik Umum. Yogyakarta: Rineka Cipta.

.2009. Pengantar Semantik Bahasa Indonesia. Jakarta: PT Rineka. Cipta.

Dardiri. 2008. Analisis wacana. Yogyakarta: UNY Press.

Dalman. (2015). Menulis karya ilmiah. Depok: Rajagrafindo Persada.

Djajasudarma, T. Fatimah. 2006. Metode Linguistik Ancangan Metode Penelitian dan Kajian. Bandung: PT. Eresco.

Djuharie-Suherli. 2001. Panduan Membuat Karya Tulis: Resensi, Laporan Buku, Skripsi, Tesis, Artikel, Makalah, Berita Essei, dll. Yrama Widya: Bandung..

Keraf, Gorys. 2001. Tata Bahasa Indonesia. Cetakan kesepuluh. Jakarta: Ikrar Mandiri Abadi.

Mulyana. 2005. Kajian Wacana: Teori, Metode, dan Aplikasi Prinsip Analisis Wacana. Yogyakarta: Tiara Wicana.

Moleong, Lexy. J. 2016. Metodologi Penelitian Kualitatif Edisi Revisi. Bandung: PT. Remaja Rosdakarya.

Semi, M. Atar. 2003. Menulis Efektif. Padang: Angkasa Raya.

Sukmadinata, Nana Syaodih. 2007. Metode Penelitian Pendidikan. Bandung: Rosdakarya.

Sumarlam. 2003. Teori dan Praktik Analisis Wacana. Surakarta: Pustaka Cakra.

Suparno. 2009. Pendidikan Vokasional bagi Kelas Menengah Atas. Bandung: Alfabeta.

Tarigan, Henry Guntur. 2008. Membaca Sebagai Suatu Keterampilan Berbahasa. Bandung: Angkasa.

Wedhawati, dkk. 2006. Tata Bahasa Jawa Mutakhir. Yogyakarta : Kanisius. 